\title{
Denial of Responsibility and Normative Negation
}

\author{
Federico L.G. Faroldi \\ University of Pisa, Pisa, Italy \\ University of Florence, Florence, Italy \\ federico.faroldi@for unipi.it
}

\begin{abstract}
In this paper I provide some linguistic evidence to the thesis that responsibility judgments are normative.

I present an argument from negation, since the negation of descriptive judgments is structurally different from the negation of normative judgments. In particular, the negation of responsibility judgments seem to conform to the pattern of the negation of normative judgments, thus being a prima facie evidence for the normativity of responsibility judgments. I assume - for the argument's sake - Austin's distinction between justification and excuse, and I sketch how to accommodate the distinction between internal (justification) and external (excuse) negation of responsibility within a language with a second-order analogous of existential generalization and $\lambda$ operator.

In the end I confront with and refute some objections against this argument.
\end{abstract}

Keywords: Responsibility, Negation, Excuses, Justifications.

\section{Introduction}

In this paper I suggest that negations of responsibility judgments are isomorphic to the negation of normative sentences. It is only external negation that inverts the value of responsibility judgments, thus providing a a prima facie evidence to consider responsibility judgments non-descriptive and normative-like.

First, I contrast two sorts of negation: negation of normative sentences and negation of descriptive sentences, pointing out where they differ. My provisional hypothesis is that internal negation and external negation work in opposite ways for descriptive sentences and normative sentences. (i) In descriptive sentences internal negation inverts their (truth) value ${ }^{1}$ whereas (ii) in normative sentences it is external negation that changes their (normative) value.

Second, I consider denials of responsibility. I show that negation of responsibility judgments falls under case (ii). It is only external negation that inverts the value of responsibility judgments, thus suggesting at least an analogy between responsibility judgments and normative judgments.

\footnotetext{
${ }^{1}$ Of course the value inversion occurs only in classical two-valued logic. In multivalued logics, it assigns its complement. This observation applies every time I mention truthvalues. 
In the end of this paper I confront with three apparently possible objections to my argument: first, I have begged the question in the definition of responsibility judgments; second, all I have shown is that external negation inverts the value of sentences if they are not descriptive, but this tells nothing about the exact nature of those sentences; third, that these features of negation hold for other modalities, so there is nothing special about normativity. This paper aims at clarifying the various kinds of negation in logic and natural language (in $\S 2$ ). It then advances an interpretation of normative negation ( $\S 3$ ) and considers how this model might shed light on responsibility judgments and in particular on negative responsibility judgments $(\S 4)$.

\section{Negation, Negations}

I shall now briefly introduce some concepts I use in this paper, namely: (i) the difference between negation, denial and rejection; (ii) the difference between logical negation, and natural language negations, including internal vs external negation and metalinguistic negation. ${ }^{2}$

\subsection{Negation, Denial, Rejection}

For the purposes of this chapter, I shall adopt the now common distinction among negation, denial and rejection. ${ }^{3}$ While these definitions are apodictically stated, nothing significant for my arguments relies on them.

Very roughly, negation acts on contents. For instance, 'unhappy' is the negation of 'happy'. ${ }^{4}$

Denial is, instead, an act. It can be either a linguistic act, or a non-linguistic act (for instance: shaking one's head).

Rejection is, instead, a mental attitude. ${ }^{5}$

\subsection{Internal vs. External Negation}

Due to a felicitous intuition in [26], ${ }^{6}$ the well-known sentence:

(1) The King of France is not bald

can be given two readings, usually paraphrased as follows: ${ }^{7}$

${ }^{2}$ For an engaging yet theory-driven introduction to negation, see [17].

${ }^{3}$ For a survey on the matter, see [24]. The paper discusses even some theories about the respective relationships among negation, denial and rejection.

${ }^{4}$ We got 'un', in English, from a reconstructed *en-, from Proto-Indoeuropean *n(probably zero grade of $*^{n e-}$ ), prefix usually found in most Indo-European tongues, cf. at least $[6,23,38]$.

${ }^{5}$ On rejection, see $[12,19,31,34]$.

${ }^{6}$ As far as I am aware, [10] (for instance in [10]) did not notice this phenomenon or shunned it.

${ }^{7}$ For instance by $[17, \S 6]$. 
(1a) INTERNAL: The King of France is not-bald (is un-bald); ${ }^{8}$

(1b) EXTERNAL: It is not the case (true) ${ }^{9}$ that the King of France is bald. ${ }^{10}$

The former (1a) is usually read as an example of internal negation; whereas the latter (1b) is usually read as an example of external negation. ${ }^{11}$

In propositional logic internal negation and external negation are equivalent, that is, they both equally invert the logical value of a given sentence. ${ }^{12}$

So, for instance:

(2) Maria is brunette

changes its truth-value both in (2a) and (2b), examples of internal negation and external negation, respectively:

(2a) INTERNAL: Maria is not brunette;

(2b) EXTERNAL: It is not the case (true) that Maria is brunette.

Please keep this point in mind because it will become handy infra at $\S 3$, when we shall see that internal negation and external negation are not equivalent in normative sentences. ${ }^{13}$

\subsection{Metalinguistic Negation}

Metalinguistic negation is defined ${ }^{14}$ as a formally negative utterance used to object to a previous utterance on any grounds (even of intonations, assertability, and so on).

\footnotetext{
${ }^{8} \exists x(\forall y(K x f \leftrightarrow y=x) \wedge \neg B x)$

9 'True' was proposed by [20].

$10 \neg \exists x(\forall y(K x f \leftrightarrow y=x) \wedge B x)$

$11[17, \S 6]$ questions the use of 'true' and underlines how no known natural language employ two distinct negative operators corresponding directly to internal and external negation, even if a given language employs two (or more) negative operators, for instance (former: declarative negation; latter: emphatic negation): Ancient Greek: 'ou' vs. 'mē'; Modern Greek: 'den' vs. 'me'; Hungarian: 'nem' vs. 'ne'; Latin: 'non' vs. 'nē'; Irish: 'nach' vs. 'gan'; Sanskrit: 'na' vs. 'mā'. There is another 'un-' in English which is not a negative operator, but it is analogous to German 'ent-' as in 'un-fold', 'ent-falten'. See Horn's interesting list of languages with distinct negative operators at p. 366.

12 But please keep in mind that duplex negatio affirmat only in propositional logic and some natural languages, for instance contemporary standard English. Both in Old and Middle English, along with contemporary languages such as Italian, Portuguese and many others, duplex negatio $n$ e $g$ a $t$.

13 This point was noticed also by St. [2]: "dicimus etiam nos "non debere peccare" pro "debere non peccare". Non enim omnis, qui facit, quod non debet, peccat, si proprie consideretur." Cf. [28, p. 36]. For an interesting survey of modal logics in Anselm, see $[15]$ and $[36,37]$.

${ }^{14}$ For instance by $[18,17]$.
} 
Here is an example of metalinguistic negation:

(3) John didn't manage to pass his viva - it was quite easy for him. (Emphasis signals stressed intonation here.)

(4) Ben is meeting a man this evening. No, he's not - he's meeting his brother.

So one does not object to the truth of a sentence, but to its (felicitous, appropriate) assertability.

Another interesting feature of metalinguistic negation is its inability to be incorporated prefixally:

(5) The King of France is not happy (*unhappy) - in fact there isn't any king of France. ${ }^{15}$

\subsection{Illocutionary or Neustic Negation}

Introduced as "neustic" negation by Hare ([14, p. 21] [13, p. 35]) and later called "illocutionary" negation (originally by Searle, cf. $[22,29]$ ), it should apply to what expresses illocutive force in a sentence or the neustic.

Here it is an example.

(8) I promise to come.

(9a) I promise not to come.

(9b) I don't promise to come.

According to Searle, (9a) is simply a propositional (or internal) negation, whereas $(9 \mathrm{~b})$ is an example of illocutionary negation: one denies the very linguistic act, not its content. (9a) and (9b) are not equivalent.

Illocutionary negation, if it exists, seems non-truth conditional. Is it assimilable to metalinguistic negation? As [21] maintains, not always: in fact metalinguistic negation need not to be expressed linguistically, whereas illocutionary negation is necessarily linguistic.

Some doubts about the very existence of illocutionary (or neustic) negation are expressed by $[7,11,16]$ and $[21]$.

[16] has proposed a very interesting reading of illocutionary negation not as external or metalinguistic negation (ie, a negation of the whole speech-act), but simply as an internal negation.

According to him,

(10) It is not the case (that) I promise to come

it is not equivalent to $(9 \mathrm{~b})$.

But (9b) must be read not as the internal negation of the coming, but as the negation of promise (as in not-promise):

(9b) I don't promise to come.

(9b) would be - at most - the negation of a preceding speech-act, rather the negation of that very speech-act produced by uttering (9b).

\footnotetext{
$\overline{15 \text { [17, p. 392] }}$.
} 
To Sum Up. First, there is logical negation. Logical negation is a logical operator (for instance: ' $\neg$ ') which is unambiguous: it always inverts the truth-value of a given sentence $p \cdot{ }^{16}$ Moreover, internal (logical) negation and external (logical) negation are functionally equivalent. ${ }^{17}$

Second, there is natural negation, ie negation in natural languages. As we have seen supra, negation in natural languages is much more complex a phenomenon than logical negation. Firstly, it may be pragmatically ambiguous (as $[17, \S 6]$ and [32] masterly argued); secondly, other than descriptive negation, natural negation can be realized externally or metalinguistically, and it is not the case that it be always used to act on the truth of a given sentence; thirdly, nondescriptive negation cannot always be semantically analyzed in terms of external or metalinguistic negation, because there are pragmatic phenomena (intonation, phonetics, etc.) involved: external or metalinguistic negation can be realized implicitly, without fixed semantic features ('it is not the case that', 'it is not true that', etc.). Fourthly, not all (negated) sentences in natural language are truth-functional, but they may be commands, prayers, wishes or insults.

Third, natural negation, for instance via metalinguistic negation, can be used not only to invert the truth-value of a sentence, but also to reject or question its assertability.

\section{Normative Negation}

Last section was devoted to analyze different kinds of negation in logic and natural languages.

In this section I try to give an account of normative negation. I maintain that it can be differentiated from non-normative negation because normative negation cancels (at least) one of its presuppositions, whereas non-normative negation preserves the presuppositions of the negated sentence.

I have argued elsewhere that is not possible to have distinct species of negation for descriptive and normative language, but only different realizations of a single attitude. ${ }^{18}$ I therefore propose to extend the model we have sketched in the preceding sections to normative language.

We have seen that logical negation, although unambiguous, is quite limited. Natural negation is instead a complex phenomenon, it does not always act on truth-values and it can be pragmatically ambiguous, divided among at least internal and external or metalinguistic negation.

Moreover, following $[17, \S 6]$, we have noticed that at least metalinguistic negation is a formally negative utterance used to object to a previous utterance on any grounds, especially its assertability.

\footnotetext{
${ }^{16}$ In many-valued logics, it assigns $p$ 's truth-value complement. In logics with more than one negation, they are nonetheless unambigous.

17 Of course I am referring here to classical propositional logic. Intuitionistic logics do not accept the equivalence of internal and external negation, nor the law of double negation: $\neg \neg B \neq B$.

18 See $[9, \S 5]$.
} 
I propose to extend this model also to normative language. To stick to a logical level, even [25, §§31-2] noticed that while external and internal negation are functionally equivalent in propositional logic, internal negation and external negation differ quite radically in deontic logic: the fact you are under an obligation not to teach deontic logic $(O \neg \delta)$, for instance, it is quite different from the fact you are not under an obligation to teach deontic logic $(\neg O \delta)$.

In an analogous fashion, I maintain that internal normative negation keeps the sentence binding or, so to speak, normative, only to invert its deonticity: from obligatory to forbidden, and so on. ${ }^{19}$ (Please note that I am not forced to assign normative sentences truth-aptness, because truth does not tell us the whole story even when (non-normative) natural language is concerned.)

External or metalinguistic negation is a rejection of the assertability (lato sensu) of a prima facie, allegedly normative sentence. Specifically, though, rejection of the assertability of a normative sentence is (implicity, I maintain) not a normative judgment, but a judgment on its normativity (or bindingness, or you name it). If a speaker feels ${ }^{20}$ a given (non-normative) proposition unassertable, he rejects it metalinguistically; if he feels a given (prima facie normative) proposition not binding or not normative, he rejects it metalinguistically or externally, canceling its presupposition of normativity. ${ }^{21}$

Consider the following normative sentence:

(1) Abortion is wrong

and its prima facie negation:

(2) Abortion is not wrong.

Both are moral (normative) judgments, and share - among others - the following presupposition:

(0) Abortion can be an object of a genuine moral judgment.

Now consider external negation of $(1):^{22}$

(3) It is not the case that abortion is wrong.

Now, while (2) is still a normative judgment, (3) seems intuitively a judgment on the normativity of (1).

(3) cancels (1)'s and (2)'s presupposition (0), because it simply rejects that abortion can be object of (that) moral judgment.

Let's now make a comparison with internal and external negation of nonnormative sentences.

Let's consider

(4) He stopped beating his wife

${ }^{19} \mathrm{I}$ am well aware that not all normative sentences (or propositions) are in deontic terms. This was only an example to illustrate the general principle I want to bring forth.

${ }^{20}$ Please note that 'to feel' here is used generally has no intended reference to emotivism or expressivism.

${ }^{21}$ I am using this as a sort of a term of art, in order to make a general point without supporting a substantive theory of normativity either in terms of reasons (cf. for instance $[27,30]$ ), good (cf. [35]) or oughts.

${ }^{22}$ Of course it can be realized also metalinguistically. 
its internal negation:

(5) He didn't stop beating his wife

and its external negation:

(6) It's not true that he stopped beating his wife.

Neither (5) nor (6) modify the ("factive") presuppositions of (4) such as that he has a wife, and he used to beat her.

Since - as we have seen - not every instance of external or metalinguistic negation is analyzable with distinct semantic (or, for that matter, syntactic) features, I assume a paraphrase in terms of external negation will account for the phenomenon, at least for our present purposes.

Considering the problem with normative negation only from the point of view of truth is quite limited, because truth does not tell the whole story even in nonnormative negation, as I pointed out in the case of metalinguistic negation. This turns out to be a plus, because normative sentences are usually not considered truth-apt. $^{23}$

In this section I contrasted descriptive and normative sentence by considering negation. I showed that normative negation, usually realized externally or metalinguistically, cancels its presupposition(s) of normativity.

Next section applies this conclusion to judgments of responsibility, showing that their structure with respect to negation is akin to normative sentences.

\section{Denial of Responsibility}

In last section I contrasted descriptive and normative sentence by considering negation. I suggested that normative negation, usually realized externally or metalinguistically, cancels its presupposition(s) of normativity.

In this section, I apply these results to judgments of responsibility, in order to provide an argument to the thesis that responsibility judgments are normative,

\footnotetext{
${ }^{23}$ And consequently one may maintain that (a) what you negate is not their truth; or that (b) norms cannot be negated. (a) was the position of the very first philosopher known to have written on this topic: Jerzy Sztykgold. In [33], he argued that you cannot negate the truth of norms, but only their righteousness [stuszność] in terms of non-righteousness [niestusznośćc. (Righteousness and unrighteousness are, for Sztykgold, the strict análogon of truth and falseness.)

(b) was instead the position of Karel Engliš ([8]), according to which:

(i) logical operations are possible only for "descriptive judgments" [soudy]);

(ii) negation [popřeni] is a logical operation;

(iii) norms $[$ normy $]$ and postulates [postuláty], although sentential, are not "descriptive judgments";

and therefore

(iv) logical operations don't apply to norms and postulates.

In particular:

(v) norms cannot be negated.

Of course Engliš' argument shows - at most, if premise (i) holds - that negation as a logical operator doesn't apply to norms. But negation is not exclusively a logical operator. Negation exists outside logic, in natural language, with different characteristics.
} 
and namely an argument "from negation". I shall show that when one denies responsibility, what happens is (a) what happens when one denies normative statements; (b) what happens is the case only when normative entities are concerned. This might show that judgments of responsibility are normative. ${ }^{24}$

Here is a more schematic version of my fourth argument:

1. when you deny a responsibility judgment, what happens (what obtains) is a cancelation of its presuppositions;

2. canceling of presuppositions obtains only when normative judgments are negated;

3. Therefore, responsibility judgements are normative judgments.

Let's begin. I shall use negation a test to isolate a normative entity. We have seen back in $\S 3$ that negation of descriptive and normative entities differs in at least one substantial point: internal and external negation work in opposite ways.

Here is an example for descriptive statements:

Internal negation (1) "John isn't tall'

$v s$.

External negation (2) "It's not the case that John is tall"

Now, let's take a normative statement (for simplicity's sake, I shall consider an imperative):

Internal negation $O(\neg W)(3)$ : "Don't shut the window!" (that is: "Shut not the window").

Note that (3) and its "positive"

(3a) Shut the window

share a presupposition of normativity.

Now, (3a)'s external negation:

External negation $\neg O(W)$ (4a) "I do not accept that is the case of shutting the window" / (4b) "I do not accept the command 'Shut the window" / (4c) "I don't care". ${ }^{25}$

instead, rejects (cancels) the presupposition of normativity that both (3) and (3a) shared.

${ }^{24}$ This is by no means the standard theory. When judgments of responsibility are kept separate from responsibility or concepts of responsibility, they are usually considered non-normative; for example, judgments of responsibility are considered explanatory by $[5,4]$. Anderson ([1, §3.1] and p.c.) considers responsibility judgments to be normative, even though he does not provide any arguments for this thesis.

${ }^{25}$ Of course I am aware these are only some possible paraphrases — there might be many more. The most important fact is that internal and external negation can be consistently kept separable. 
As I explained in $\S 2$, for descriptive sentences it is internal negation that might change their truth-value (from truth to false and viceversa); vice versa, for normative (imperative, in this case) sentences, it is external negation that changes their normativity-value, by rejecting the presupposition of normativity.

Now, let's apply this test to responsibility.

Internal negation (5) "He is not responsible for killing A, because..."

$v s$.

External negation (6) "It is not the case that he is responsible for killing A, because..." /

Now, if (5) stands to (1) as (6) stands to (2), we can confidently conclude that (5) and (6) are statements analogous to (1) and (2), that is, non-normative.

Quite on the contrary, if (5) stands to (3) as (6) stands to (4), we can confidently conclude that (5) and (6) are statements analogous to (3) and (4), that is, broadly normative.

It turns out, unfortunately, that you cannot really tell if (5) - internal negation of responsibility - tells us something of significance, for the very simple reason that its interpretation requires an understanding of responsibility. If you think responsibility is an objective state-of-affairs, that can be somehow empirically ascertained, then you would interpret (5) as a descriptive statement, whose truth-value is to be checked against the world; and vice versa.

Therefore, let's turn to (6) to seek some clarification of the matter.

My hypothesis is that a statement such as (5) stands for a justification; while (6) stands for an excuse. I take advantage of the paradigm excuse vs. justification developed in [3].

With a justification, I maintain, we remain in the domain of the normative: we accept A, and even add some reasons for it. The presupposition of normativity is kept.

Quite on the contrary, an excuse, in a way, suspends what was going on, it makes "normativity freeze" because it refers to conditions other than the very act A, conditions that (by definition) rule out responsibility (duress, infancy, mental incapacity, maybe psychopathy for moral responsibility). The presupposition of normativity is canceled.

In the words of Austin:

[i]n the one defence [= justification], briefly, we accept responsibility but deny that it was bad: in the other [= excuse], we admit that it was bad but don't accept full, or even any, responsibility ([3]).

it is not quite fair or correct to say baldly "X did A". We may say it isn't fair just to say $X$ did it; perhaps he was under somebody's influence, or was nudged. Or, it isn't fair to say baldly he did A; it may have been partly accidental, or an unintentional slip. Or, it isn't fair to say he did simply $A$ - he was really doing something quite different and A was only incidental, or he was looking at the whole thing quite differently ([3, p.2]). 
First, excuses are denial of responsibility because, in giving excuses, a person contests or opposes a previously ascribed responsibility, by rejecting constitutive elements of the accusation: for instance, by denying having committed anything. He simply denies that the previous ascription of responsibility is sound.

Second, excuses are rhetic (and not thetic) negations (denials) of responsibility because they do not seek to cancel or nullify responsibility, since they assume that there is no responsibility whatsoever. Absence of responsibility is constitutive of excuses: if there were responsibility, they would not be excuses but - at most - justifications. Excuses do not presuppose responsibility, but only ascription of responsibility. ${ }^{26}$

Justifications, instead, are not at all negations of responsibility because justifications presuppose responsibility: justifications affirm responsibility, but deny it is responsibility for something bad. (A paradigmatic example seems to me "self defense": $a$ admits to having killed $b$, but $\mathrm{b}$ was assaulting him with a knife, for instance.)

Negative Properties and Existential Generalization. A possible way to account for the difference between internal and external negation, and the existence of a given property is to consider a plausible analogous of Existential Generalization at the second order (I am not arguing for it at this point; I shall only make my point with a somewhat sloppy notation).

(EG1) $F a \models \exists x F x$

(1) $\neg F a \not \models \exists x F x$

But with a $\lambda$ operator we can gain negative properties:

(2) $\lambda x(\neg F x) a \models \exists x(\neg F x \wedge x=a)$

Likewise, it is plausible to hold the following:

(EG2) $F a \models \exists P \exists x(P x \wedge x=a \wedge P=F)^{27}$

(3) $\neg F a \not \models \exists P \exists x(P x \wedge x=a \wedge P=F)$ but

(4) $\lambda P \lambda x(\neg F x) a \models \exists P \exists x(P x \wedge x=a \wedge P=\lambda x(\neg F x))$

While both (1) and (3) are plain external negations and don't license any inference to the existence of either something or some property; (2) and (4) can, with the use of $\lambda$-abstraction, represent internal negation. Internal negation seems to license an inference to the existence of some property of sort.

The connection with internal and external negation of responsibility, while stretched, is significant: in fact, we suggested that with external negation of responsibility (excuse) there is no more responsibility (and normativity) involved, whereas with internal negation of responsibility (justification) the normativity is kept.

${ }^{26}$ As I noted with accusations, not all excuses are pled using a verb like 'to excuse' or 'scusare'; in an analogous fashion, it is not only the use of 'to excuse' or 'scusare' that can make an excuse.

${ }^{27}$ Of course one needs to explain what ' $=$ ' among $\mathrm{P}$ and $\mathrm{F}$ means. I thank Tim Williamson for discussion on this point. 
Two Examples: Excuses vs. Justifications. I am going to illustrate the difference between justification and excuses. I ask the reader to imagine two fictional criminal cases (both involve a death), and to abstract from particular legal systems in order to focus on the general point.

In the first, let's call it WIFE, a man comes back home and sees an intruder trying to rape or kill his wife. By chance, there is the intruder's loaded gun at hand. The man takes it up, aims and finally shoots the intruder down - killing him. In court, he admits the murder and puts forward his reasons. His lawyer says: "Look, he is not responsible for the killing, because that was self-defence: he was trying to defend and save his own wife." This is a justification: you admit your deed (there are all the relevant required elements: actus reus, mens rea, volition, intention, knowledge and so on to make that killing a murder) but you have a (good) reason for you action.

In the second, let's call it MAD, a mentally-ill man escapes from a psychiatric hospital, manages to get a gun, and shoots down a random passer-by. His lawyer says: "Look, he is not responsible for the killing, because it is not the case he is (= can be) responsible at all: he is mad (under duress, in infancy...)." This is an excuse: you may admit the deed, but it was done without the relevant required conditions: without mens rea, for instance, or without those capacities required for a death or a killing to be a murder.

To sum up, with a justification you deny your responsibility for that deed qua a particular action (but you admit, nonetheless, that you are under the domain of responsibility, that you can be responsible); with an excuse you deny your responsibility tout court, you deny that you are under the very domain of responsibility.

The lawyer's sentence in WIFE: "he is not responsible for the killing" is comparable to (3): "Don't shut the window" and (5): "He was not responsible", inasmuch as they are internal negations.

On the contrary, the lawyer's sentence in MAD: "it is not the case he is (= can be) responsible at all" seems to me analogous to (4): "It is not the case you order me to shut the window" and (6): "It is not the case that he is responsible for A, because..."

As (3) conserved the imperative nature of the sentence, so WIFE conserved the domain of responsibility. As (4) instead went out the domain of the imperative, to make a non-imperative claim, in the same way MAD appealed to a condition — in a way a non-normative, even factual condition — to be excluded from the domain of responsibility.

This linguistic evidence is consistent with the conceptual arguments I put forward earlier in this section: while justifications aren't at all denial of responsibility because they presupposes responsibility, excuses are in fact denial of responsibility, because they reject it.

With justifications and excuses, negation of responsibility coincides both with a linguistic act (denial) and a mental state (rejection). 
We suggested that

- (i) when we deny responsibility, we have (at least) two cases: internal negation (which stands for a justification) and external negation (standing for an excuse). Then, we have seen that

- (ii) internal negations of responsibility do not exit the domain of responsibility (they presuppose responsibility); whereas external negations do (they reject the presupposition of responsibility). But this was exactly what happened with normative sentences (as I showed in §3): internal negation keeps the sentence normative (it keeps the presupposition of normativity), whereas external negation rejects it (it cancels the presupposition of normativity).

If we suppose that this kind of negation is at work only with non-descriptive (and namely, normative statements), we can therefore conclude that

- (iii) since judgments denying responsibility are structurally akin to normative sentences, responsibility judgments are akin to normative sentences.

Caveats and Assumptions. Now, some caveats. I have limited my discussion to the word (and the concept) of responsibility in the proper, fuller sense. I am very well aware that there may be pragmatical ways to express a responsibility judgment without mentioning the word 'responsibility' or any related. I am also aware that we may get indicative (or descriptive) sentences (to express/ascribe responsibility). For this (and for other) reasons linguistic arguments are interesting but not conclusive. I offer more (non linguistic) arguments for the thesis that responsibility is normative in [9].

Last but not least, my argument makes the following assumption: there are only two kinds of language relevant to our investigation here: descriptive and normative language. This may not be the case: there are several other language domains I am not considering: prayers, exclamations, insults, whose "status" with regard to negation is unclear. Therefore, it might be the case that the different ways negation works (in descriptive and normative domains) is not exclusive: negation might work in prayers as in normativity, and the second premise of my argument would be factually undermined. Assuming the prima facie evidence I discussed as conclusive might be too strong, and other interpretations are certainly possible depending on substantive theories of normativity, modality, and responsibility. But even if in general this argument does not prove to be conceptually unassailable, I think it is still very telling.

Objections. I consider here three possible objections to my argument: first, I have begged the question in the definition of responsibility judgments; second, all I have shown is that external negation inverts the value of sentences if they are not descriptive, but this tells nothing about the exact nature of those sentences; third, these features of negation may be shared by other kinds of modality, so there is not special about normativity.

To the first objection, I put forward a twofold reply: first, there is no shared consensus either on what responsibility is or on what responsibility judgments 
are: a degree of arbitrariness is needed anyway; second, there is no conceptual reason precluding my analysis to be extended further, given the right premisses.

To the second objection, I reply that I have at least shown that responsibility judgments are not descriptive; nonetheless I believe a linguistic test such as mine cannot exhaust the richness of human practices - in other words, normativity is not a sheer linguistic notion.

To the third objection, I reply that, examples with "oughts" notwithstanding, it is not clear whether normativity is a modality or not (it may be a property, for one). Moreover, other modalities may be normative as well (recently [30] so argued for necessity, the a priori, and other modalities), and thus these features of negation shouldn't come as a surprise.

Acknowledgements. For discussion on various points, suggestions, and critiques I thank Amedeo Giovanni Conte, Mattia Bazzoni, Guglielmo Feis, Sergio Filippo Magni, Timothy Williamson and two anonymous referees.

\section{References}

1. Anderson, S.: Coercion. In: Zalta, E.N. (ed.) The Stanford Encyclopedia of Philosophy (Winter 2011)

2. Anselm of Canterbury. "Lambeth's Fragments". In: Schmitt, F.S. (ed.) Ein neues unvollendetes Werk des hl. Anselm von Canterbury. Aschendorff, Münster i W (1936)

3. Austin, J.L.: A Plea for Excuses: The Presidential Address. In: Proceedings of the Aristotelian Society, vol. 57, pp. 1-30 (1956)

4. Björnsson, G., Persson, K.: A Unified Empirical Account of Responsibility Judgments. In: Philosophy and Phenomenological Research (forthcoming)

5. Björnsson, G., Persson, K.: The Explanatory Component of Moral Responsibility. Noûs 46(2), 326-354 (2012)

6. Brückner, A.: Słownik etymologiczny jezyka polskiego. Wiedza Powszechna, Warszawa (1957)

7. Cohen, L.J.: Do Illocutionary Forces Exist? The Philosophical Quarterly 14, 118-137 (1964)

8. Engliš, K.: Postulát a norma nejsou soudy. In: Casopis pro právní a státní vědu XXVIII, pp. 95-113 (1947)

9. Faroldi, F.L.G.: The Normative Structure of Responsibility. Law, Ethics, Neuroscience (forthcoming)

10. Frege, F.L.G.: Der Gedanke: Eine logische Untersuchung. In: Beiträge zur Philosophie des Deutschen Idealismus I, pp. 58-77 (September 1918)

11. Garner, R.T.: Some Doubts about Illocutionary Negation. Analysis 31, 106-112 (1971)

12. Gomolińska, A.: On the Logic of Acceptance and Rejection. Studia Logica 60(2), 233-251 (1998)

13. Hare, R.M.: Some Sub-Atomic Particles of Logic. Mind 98, 23-37 (1989)

14. Hare, R.M.: The Language of Morals. Clarendon Press, Oxford (1952)

15. Henry, D.P.: St. Anselm on the Varieties of 'Doing'. Theoria 19, 178-183 (1953)

16. Hoche, H.-U.: Do Illocutionary, or Neustic, Negations Exist? Erkenntnis 43, 127-136 (1995) 
17. Horn, L.R.: A Natural History of Negation. University of Chicago Press, Chicago, Illinois (1989)

18. Horn, L.R.: Metalinguistic Negation and Pragmatic Ambiguity. Language 61(1), 121-174 (1985)

19. Incurvati, L., Smith, P.: Rejection and Valuations. Analysis 70(1), 3-10 (2010)

20. Karttunen, L., Peters, S.: Conventional Implicature. In: Oh, C.-K., Dinneen, D. (eds.) Syntax and Semantics 11: Presupposition, pp. 1-56. Academic Press, New York (1979)

21. Moeschler, J.: Negation, Scope and the Descriptive/Metalinguistic Distinction. Generative Grammar in Geneva 6, 29-48 (2010)

22. Peetz, V.: Illocutionary Negation. Philosophia: Philosophical Quarterly of Israel 8, 639-644 (1979)

23. Pokorny, J.: Indogermanisches etymologisches Wörterbuch. Francke (1994)

24. Ripley, D.: Negation, Denial, and Rejection. Philosophy Compass 6(9), 622-629 (2011)

25. Ross, A.C.N.: Directives and Norms. Humanities Press, New York (1968)

26. Russell, B.: On Denoting. Mind 14(56), 479-493 (1905)

27. Scanlon, T.M.: Being Realistic about Reasons. Oxford University Press, Oxford (2014)

28. Schmitt, F.S.: Ein neues unvollendetes Werk des hl. Anselm von Canterbury. Aschendorff, Münster i W (1936)

29. Searle, J.R., Vanderveken, D.: Foundations of Illocutionary Logic. Cambridge University Press, New York (1985)

30. Skorupski, J.: The Domain of Reasons. Oxford University Press, Oxford (2010)

31. Smiley, T.: Rejection. Analysis 56(1), 1-9 (1996)

32. Speranza, J., Horn, L.R.: A Brief History of Negation. Journal of Applied Logic 8(3), 277-301 (2010)

33. Sztykgold, J.: Negacja normy. Przeglad filozoficzny 39, 492-494 (1936)

34. Tamminga, A.: Logics of Rejection: Two Systems of Natural Deduction. Logique et Analyse 146, 169-208 (1994)

35. Thomson, J.J.: Normativity. Open Court, Chicago, Illinois (2008)

36. Uckelman, S.L.: Anselm's Logic of Agency, Amsterdam: Institute for Logic, Language and Computation (ILLC). University of Amsterdam (2007)

37. Uckelman, S.L.: Modalities in Medieval Logic. Institute for Logic, Language and Computation, Amsterdam (2009)

38. Vasmer, M.: Russisches etymologisches Wörterbuch. C. Winter, Heidelberg (1958) 